\title{
How Japan Has Attained Great Military Power in Global Capitalism
}

\author{
Akira Uchiyama \\ Ritsumeikan University, Kyoto, Japan
}

\begin{abstract}
Japan attained great military power in around 2015 to aim at hegemony in the era of global capitalism. The most important fact is that Japan could deploy four helicopter carriers with a fleet each and make military operations independently in the whole of East Asia. Its formation has been backed up by increased yearly defense spending over the last 30 years. The existence of this military power cannot necessarily be explained from the requirements of the global capitals since they have lost their integral relationship with the originated nation. Rather, it is explained by relative independency of state activity, in particular super-power nationalism and hegemonism. These are the major driving force and the main promoter of military power, but do not have support these days from the majority of people.

Keywords: global capital, major weapon, defense spending, military operation, hegemonism, super-power nationalism
\end{abstract}

\section{Introduction}

One of the most distinctive features of global capitalism is as follows:

Global capital, i.e., globalized monopoly capitals, has made its relationship with the originated nation state weaker, losing its integral relationship with its nation since the end of 19th century, especially in the 1980s and 1990s. Under above condition, Japan attained great military power around 2015 and it has been strengthened by the Abe Administration.

The purposes of this paper are as follows: Firstly, we find out the logic behind how Japan has achieved military power under global capitalism. Secondly, we warn against Japan continuing to move towards obtaining military power.

\section{Global Capital in Global Capitalism}

One of the most distinctive features of global capitalism is that multinational enterprises (globalized monopoly capitals), namely global capitals, have made its relationship with the originated nation state weaker, losing its integral relationship with its nation from 1980s to the end of the 20th century. This is because global capitals have invested in multiple countries or have been economically active worldwide, resulting in several nation states to share common vital interests among them.

Global capitalism was established in the beginning of 21st century, after going through the process of its formation in the 1980's and 1990's. Monopoly capitals (large companies) in monopoly capitalism within a

Akira Uchiyama, Dr. of Economics, senior fellow, Institute of Social Science, Ritsumeikan University, Kyoto, Japan. 
single country have become the global capitals which are now dominant and economically active in each national economy and over the world economy. Global capitalism is a new stage of capitalism that has shifted away from monopoly capitalism accompanied by a welfare state. Besides, both the model of advanced countries and the model of emerged economies, such as Brazil, Russia, India, and China (BRICs) coexist in global capitalism, although there are significant differences between them.

By having transformed to new capitalism, national capitalism, for example, the substance of Japanese or American capitalism has already disappeared. National economy divided by borders, for example, the "Japanese economy" still exists as an inseparable part of global capitalism. This means that the independency of the national economy has been weakened remarkably.

Considering the fact that the relationship between global capitals (multinational enterprises) and nation state are not integral in global capitalism, it should be explained how the Japan has attained great military power, and if its power could be sustained, while the Japanese economy plays a core part of global capitalism.

\section{Attaining Japanese Military Power to Aim at Hegemonism}

The four conditions of possessing military power are as follows:

A country has:

1. A superior power over the neighboring states in the field of military force.

2. The capability to carry out military operations in the international region or all over the world.

3. The capacity to pay for a large defense spending (USD\$50 billion in Japan).

4. High technology industries and well-developed systematic infrastructure and laws.

With the above four conditions, a state can stand in a prominent position diplomatically and militarily in the international community.

Nowadays, Japan is clearly a military power, whose power is almost equal to the UK and France, though Japan does not possess nuclear weapons, or extended or intermediate range ballistic missiles (ERBM \& IRBM), bombers, etc. Japan started making policies to attain military power in the latter half of 1980s, and continued to strengthen its military force for more than 30 years, along with the 1st-7th Government Mid-Term Defense Plans (1986-2018). But it is not super-power, like the United States which has huge scale of military force and capability of operation.

Japan can be considered to have become a semi-military power at the end of 20th century on the following grounds: the level of military force that Japan had achieved and Japan's military performance including its declaration of the defense policy.

The Japanese army (Self-Defense Force) has been armed with large arsenal with weapons as powerful as those of a military power, such as Aegis warships with missile systems. Japan possesses the following weapons as of March 2000 (USD\$ = ¥ 100):

Four Aegis warships of Kongoh class (DDG, 7,250 t, USD\$12.2 billion each) deployed to four fleets by 1998. Four planes of the E767 mid-air early caution controlling (USD $\$ 555$ million each), three large transport ships of Ohsumi-class (LST, 8,900 t, USD\$503 million each), and 60 support fighters of F-2 (USD\$120 million each)

On the other hand, the US announced the East Asia Security Report (EASR) which is called the Nye-Initiative and was made by the leadership of J. S. Nye, Jr. According to this initiative, Japan and the US governments agreed with the new strategy of the security in the Asia and Pacific region and proclaimed the 
US-Japan Security Declaration in April 1996. The important point is that Japan rapidly increased its military presence in this region, corresponding to the size of the economy and technology, stating that "Both governments make efforts collectively and individually in order to become more peaceful and stabilized in the situations of the security of Asia and Pacific region”. This statement means that the Japanese government has declared the distinct intention to use the military force for the international community.

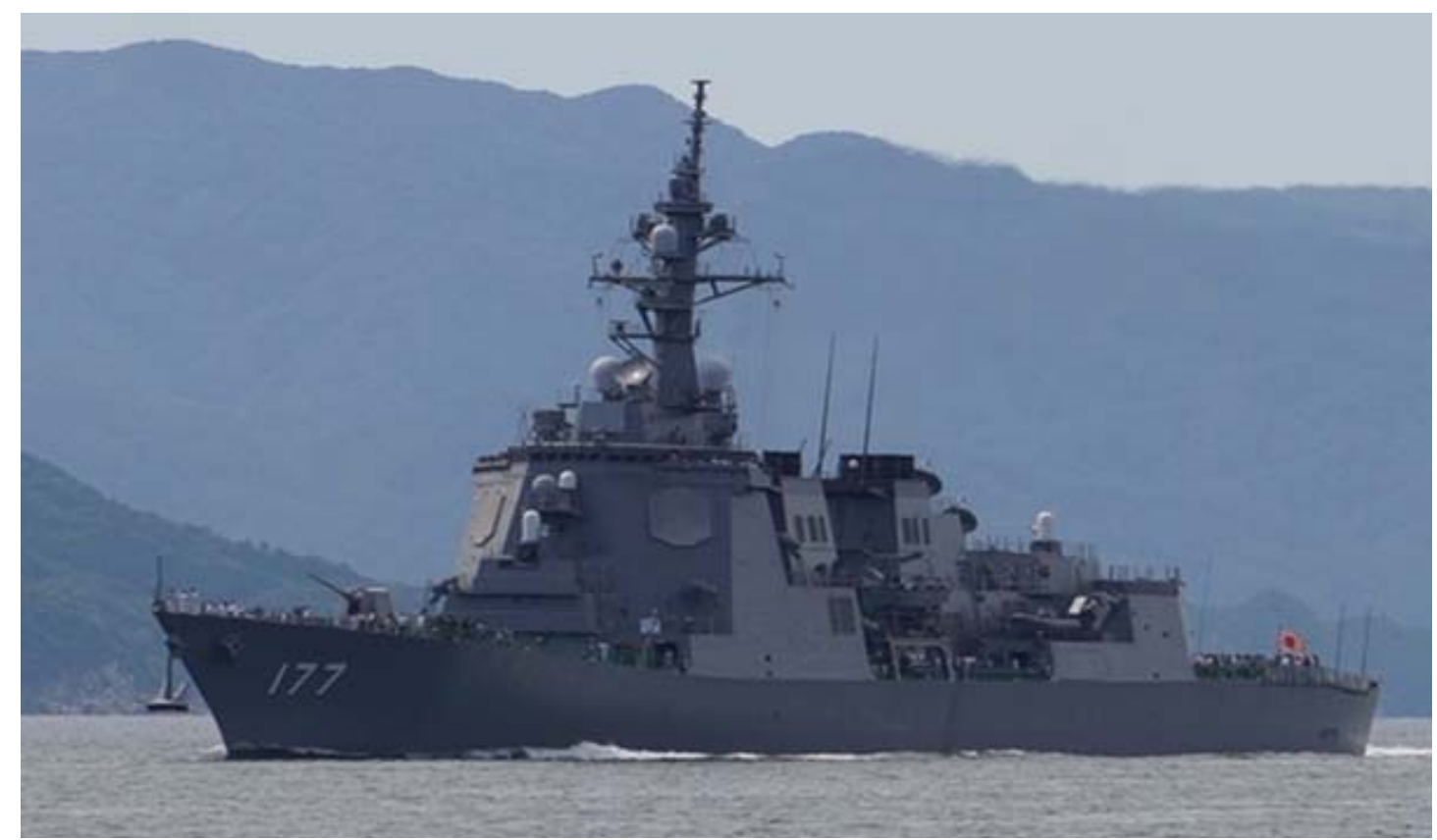

Figure 1. Two large Aegis warships of Atago-class (DDG, 7,750 t, since 2007) (Source: Japanese Defense Ministry, https://www.mod.go.jp/).

Prof. Smith (1999) pointed out that the missions of the Japan Self-Force are not only to defend its own country, but to also be able to influence the military balance in this region. After the (second) guideline, Japan-US Defense Cooperation was decided by the Japan-United States Security Consultative Committee (SCC) in September 1997, and the act of emergency-at-periphery law was enacted in 1999.

In addition, Japan participated in the Afghan Wars in 2001 and Iraq War in 2003, when the Japanese fleet was dispatched to the Indian Ocean, providing logistic support to the US and the UK armies.

However, Japan was not a military power before 2015. Although the Navy began to deploy helicopter carriers from 2009, it did not possess an aircraft carrier. Without an aircraft carrier, the Navy could not independently perform military operations in the whole area of East Asia and the Western Pacific Ocean, which meant Japan could not be classified as a military power.

Since 2000, the Japanese government has continued to strengthen its military force by procuring the newest and most high-tech weapons as well as maintaining and updating its security-related legal system. Consequently, Japan became a great military power in around 2015. The most important reason is that the Japanese Navy started to deploy four helicopter carriers as a flagship to four fleets, two of which are the larger ones of Izumo-class with 19,500 $\mathrm{t}$ in the standard displacement and $248 \mathrm{~m}$ total length. It is now possible for Japan to carry out military operations independently at all times in the wide range of over 2,000 km from Japanese islands, covering the whole of Asia and the Pacific region. Four fleets among the total of eight fleets 
in its Navy have the characteristic of a carrier strike group. ${ }^{1}$

South Korea has held three Aegis-equipped warships since 2012, and it was in 2008 that South Korea could deploy its warships for the first time. It was in 2017 and 2018 that Australia started to deploy two Aegis warships.

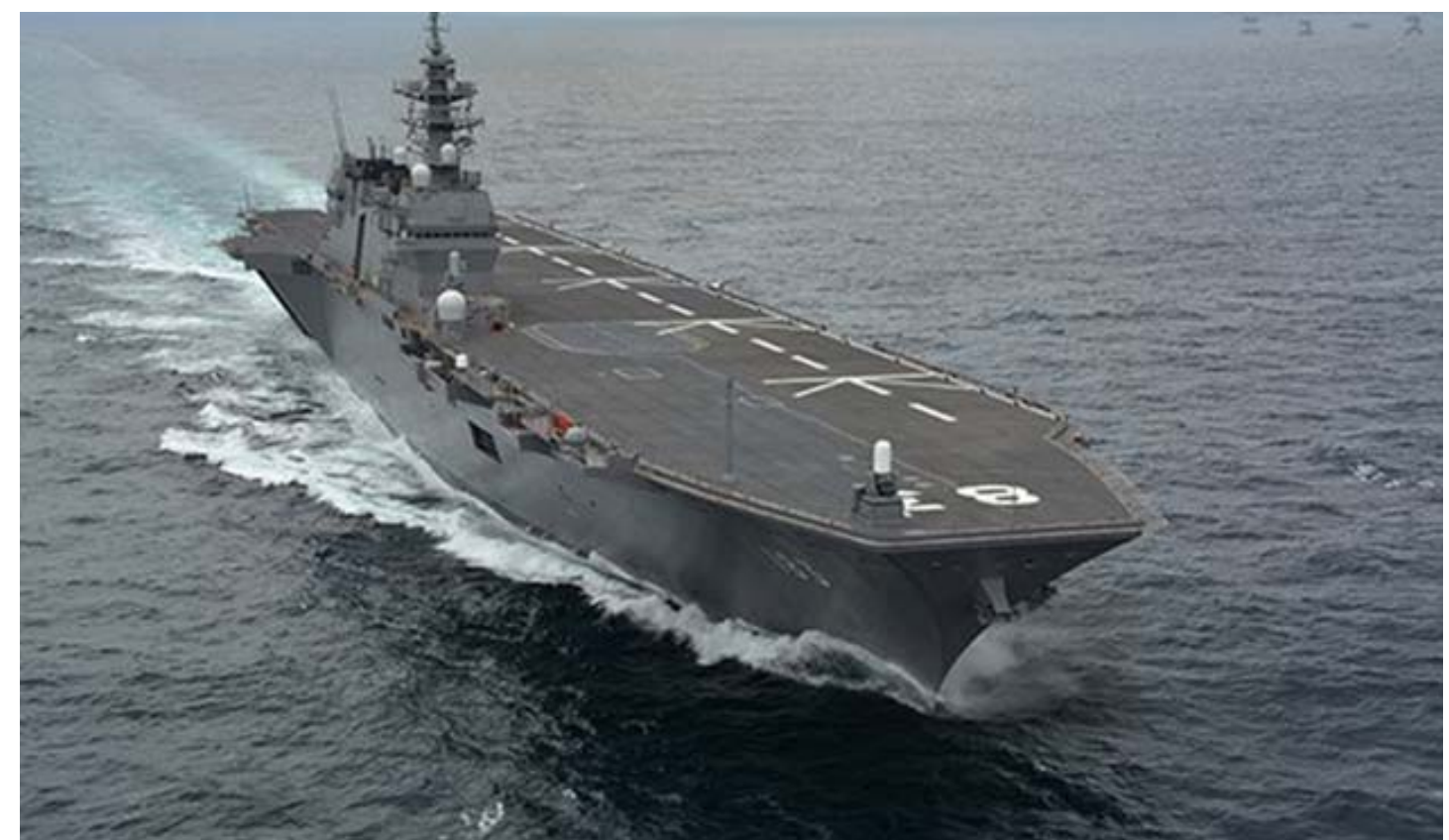

Figure 2. Large helicopter carrier (Izumo-class, 19,500 t, 248 m total length) (Source: Japanese Defense Ministry, https://www.mod.go.jp/).

Japanese Self-Defense Force possesses the following main weapons as of March 2018 (USD\$ = ¥ 100).

1. The Army. Thirteen attack Helicopters of AH-64D type (USD\$110 million per a helicopter), 52 amphibious vehicles (AAV7, USD\$7.4 million), 69 type-16 Maneuver combat vehicles (16MCV, USD\$7.6 million each), 125 air-to-air missiles of AIM-120, 13 transport aircrafts of Osprey (V22, USD\$98 million each), and two Aegis ashore arranged aerial-to-ground (USD\$1.3 billion each, from 2018).

2. The Navy-Main Warships. Two large helicopter carriers (DDH, Izumo-class, 19,500 t, $248 \mathrm{~m}$ total length USD \$1200 million each), two helicopter carriers (DDH, Hyuga-class, 13,500 t, 198 m, USD\$1,100 million each), 74 patrol helicopters of SH-60K (USD\$70 million each), two (7,250 t, USD\$1,200 million), nine new submarines of Sohryu-class (2,950 t, with the AIP, USD\$643 million), three large transport ships of Ohsumi-class (above-mentioned), two replenishment oilers of Mashu-class (13,500 t, USD\$430 million each), and two larger Aegis warships of Maya-class (DDG, 8,200 t, USD\$1,700 million, into commission in 2020 and 2021).

3. The Air Force. One aircraft of the E-2D air borne early warnings (Advanced Hawkeye USD \$260 million each, scheduled four planes), 13 air borne early warnings of the E-2C (USD\$99 million each), 10

\footnotetext{
${ }^{1}$ Brad Lendon, Senior international correspondent of CNN reported on 6th December 2016 as follows: “the country (Japan) has again established itself as one of the world's foremost military powers”, based on the opinions of experts, John T. Kuehn, a professor of military history at the Army Command and General Staff College, and Kyle Mizokami, editor of the Japan Security Watch blog and a contributor to US Naval Institute News. Updated 1303 GMT (2103 HKT) December 7, 2016. https://edition.cnn.com/.
} 
stealth fighters of F35A (USD\$131 million each, scheduled 28 fighters), 33 antisubmarine patrol planes of the P-1 class (USD\$200, scheduled 70 planes), two unmanned reconnaissance planes of Global Hawk (USD\$189 million each, scheduled four planes), and one transport aircrafts with air refueling capability (KC-46A, USD\$249 million each, scheduled three aircrafts),

Nowadays, the Japanese army can dispatch a fleet easily and carry out military operations in the whole of Asia and the Pacific region, and the Indian Ocean. In fact, Japan has performed military activities in the East China Sea and South China Sea since 2016. Moreover, Japan would possibly have the capability to arm itself with nuclear weapons within one year, if the government decides to do so, and if the international community will accept Japan's nuclear armament. This is because Japan has the highly technological base related to nuclear weapons, such as technology of nuclear power plant and that of missiles and other transporting means, such as H-2A rockets used to launch the Hayabusa-2 asteroid probe, the Venus orbiter Akatsuki, and so on. Furthermore, Japan holds 47 tons of plutonium which are the raw material for nuclear bombs and were generated from nuclear power stations in 2018. It gives Japan the capability to produce about 6,000 nuclear bombs (Todd, 2018). ${ }^{2}$

In addition, Abe Administration succeeded significantly in amending the law system related to security in the 2010s. The government affirmed the right to collective defense by changing the interpretation of the 2nd clause of Article 9 in the Constitution and by enacting new security laws in which Japanese army can carry out military action or war together with foreign army.

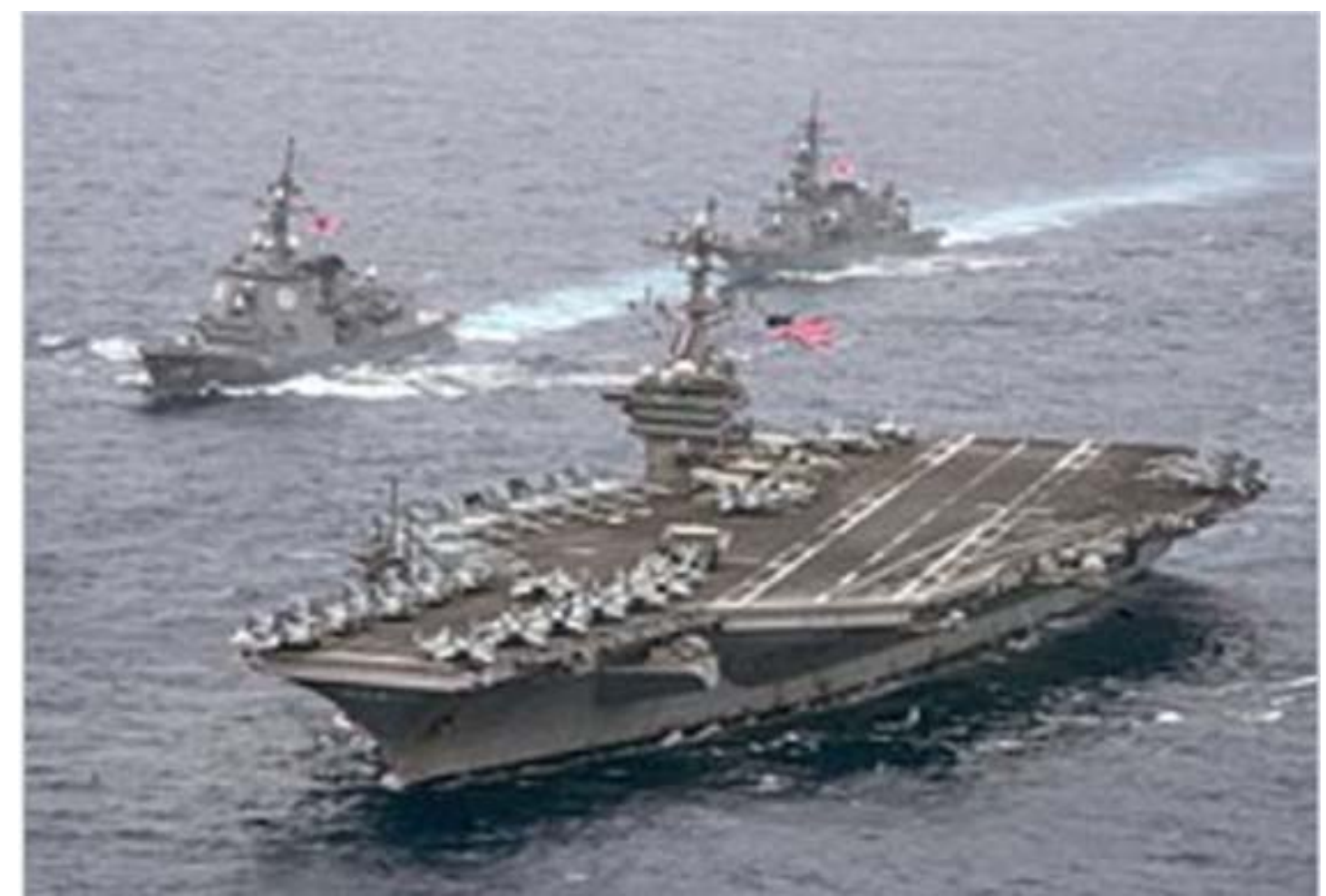

Figure 3. Japanese aegis warship and the US carrier, Carl Vinson in the US and Japan joint training in Japan Sea (Source: Japanese Defense Ministry, https://www.mod.go.jp/).

\footnotetext{
2 Todd (2018) argued that Japan should arm itself with nuclear weapons for military balance in East Asia in 2018, knowing that Japan has the capacity to do so.
} 
The Japanese government made an important decision to strengthen its military force further with the sixth defense guidelines formulated in December 2018. They will launch to modify two large helicopter carriers, Izumo and Kaga, to act as an aircraft carrier and to purchase 42 F-35B stealth fighters to put on the carriers for five years, which can take off at a short distance and land vertically, which is useful on short runways on remote islands or on aircraft carriers.

On the one hand, the move comes as China increases its maritime presence in the region. Its first aircraft carrier started service in 2012 and the Beijing government plans to build more. On the other hand, it is motivated by the Japanese government wanting to rapidly expand the strategic range and ability of Japan's military force.

The formation of Japan's military power and the strengthening of its force have been backed up by an increased yearly defense spending over the last 30 years. In particular, the total defense spending increased at its highest rate (more than $20 \%$ to 30\%) in the latter half of 1980s and the first half of 1990s. Since the latter half of 1990s, the average spending exceeded USD $\$ 49$ billion per year. It has been over USD $\$ 50$ billion since 2014, and reached USD $\$ 53.5$ billion in 2017. In addition, the deferred burden is over USD $\$ 20$ billion (USD\$23.9 billion in 2016). The sum of both is over USD70 billion per year (see Tables 1 and 2). Its size was 7th place (USD $\$ 47.3$ billion) in the world ranking in 2016, following France (5th) and the UK (6th), with South Korea 10th (USD \$33.8 billion) and Australia 12th (USD\$242 billion) in the same year (International Institute for Strategic Studies [IISS], 2017). ${ }^{3}$

Table 1

Defense Spending of 1980's-2010's (USD\$ Million)

\begin{tabular}{|l|r|r|r|r|r|}
\hline & Total & Index & $\begin{array}{r}\text { Amount of } \\
\text { Increase* }\end{array}$ & $\begin{array}{l}\text { Average } \\
\text { amount/year }\end{array}$ & $\begin{array}{l}\text { Increase } \\
\text { rate(\%) }\end{array}$ \\
\hline $1981-1985$ & 139,044 & 100 & - & 27808 & - \\
\hline $1986-1990$ & 186,120 & 134 & 47076 & 37224 & 33.9 \\
\hline $1991-1995$ & 229,885 & 165 & 43765 & 45977 & 23.5 \\
\hline $1996-2000$ & 245,252 & 176 & 15367 & 49050 & 6.7 \\
\hline $2001-2005$ & 245,913 & 177 & 661 & 49182 & 0.3 \\
\hline $2006-2010$ & 238,589 & 172 & $\triangle 732$ & 47717 & $\triangle 3.0$ \\
\hline $2011-2015$ & 245,649 & 177 & 7060 & 49129 & 3.0 \\
\hline $2016-2018 *$ & 156,933 & 188 & - & 52311 & 6.5 \\
\hline
\end{tabular}

Note. ${ }^{*}$ Five years-on-five years increase: (1) USD\$ = ¥100; (2) 2017, 2018: Budget; (3) 2016-2018: Average amount/three years.

\footnotetext{
${ }^{3}$ IISS (2017), Military Balance 2017. The expenditure of Japan Coast Guard, and the space development etc., are not included in its defense spending. Adding them, the amount of defense spending increase still more.
} 
Table 2

Defense Spending (Annual Settlement: USD\$ Million)

\begin{tabular}{|r|r|r|r|r|}
\hline & I Total & II D. B. & I $\mathrm{a}$ & II b \\
\hline 2011 & 48,181 & 20,365 & 19,680 & 685 \\
\hline 2012 & 47,615 & 20,017 & 18,468 & 1,549 \\
\hline 2013 & 47,922 & 17,728 & 16,432 & 1,296 \\
\hline 2014 & 50,628 & 22,127 & 20,896 & 1,231 \\
\hline 2015 & 51,303 & 23,941 & 22,501 & 1,440 \\
\hline 2016 & 51,498 & 23,923 & 22,405 & 1,518 \\
\hline $11-16$ Average & 49,525 & 21,350 & 20,064 & 1,287 \\
\hline 2017 & 53,524 & 22,142 & 21,343 & 799 \\
\hline 2018 & 51,911 & 21,899 & 20,127 & 1,772 \\
\hline
\end{tabular}

Notes. 2017 budget after additional one 2018 budget US\$ = ¥100; D.B. = Deferred burden; IIa = Obligatory assurance of national subsidization (Fighter etc.); IIb = Continuing expenditure (Warship etc.).

The expenditure on the purchase of weapons averages over USD\$17 billion, and makes up 35\% of the total expenditure each year from 2011 to 2018. Furthermore, over a billion USD\$ is spent on research and development, which is related to developing stronger weapons (USD\$ 1.2 billion in 2017). It is for sure that the defense spending, especially the expenditure for weapons, has made it possible for Japan to attain its military power, by supplying large quantities of powerful weapons (see Table 3).

Table 3

Structure of Defense Spending (Annual Settlement: USD\$ Million)

\begin{tabular}{|c|c|c|c|c|c|c|c|c|}
\hline & I Total & 1. Weapons & $1-a$ & $1-b$ & $1-c$ & $2 . R \& D$ & $1+2=W$ & W/ I (\%) \\
\hline 2011 & 48,181 & 16,041 & 84.7 & 24.5 & 5,103 & 905 & 16,946 & 35.2 \\
\hline 2012 & 47,615 & 17,078 & 9,791 & 2,847 & 4,440 & 919 & 17,997 & 37.8 \\
\hline 2013 & 47,922 & 16,005 & 8,671 & 2,521 & 4,813 & 1,309 & 17,314 & 36.1 \\
\hline 2014 & 50,628 & 17,565 & 9,591 & 2,233 & 5,741 & 1,294 & 18,859 & 37.3 \\
\hline 2015 & 51,303 & 17,273 & 8,979 & 2,469 & 5,825 & 1,121 & 18,394 & 35.9 \\
\hline 2016 & 51,498 & 18,193 & 9,140 & 2,717 & 6,336 & 976 & 19,169 & 37.2 \\
\hline $11-16$ 計 & 297,147 & 102,155 & 46,257 & 12,812 & 32,258 & 6,524 & 108,679 & 36.6 \\
\hline $11-16$ Average & 49,525 & 17,026 & 9,109 & 2,541 & 5,376 & 1,087 & 17,962 & 36.3 \\
\hline 2017 & 53,524 & 18,757 & 8,953 & 2,515 & 7,289 & 1,212 & 19,969 & 37.3 \\
\hline 2018 & 51,911 & 17,070 & 7,263 & 2,134 & 7,673 & 1,101 & 18,171 & 35.0 \\
\hline
\end{tabular}

Notes. 2017 budget after additional one 2018 budget; 1-a = Arilleries and veicles; 1-b = Warships and vessels; 1-c = Planes for war; R \& D: Research and development.

\section{Logic Behind How Japan Attained Military Power in Global Capitalism}

Global capitals originated in Japan have invested in many countries, which does not necessarily require Japan to be a great military power, even if they have to pay the necessary cost for the political and social stability in those regions. We should find out how Japan attained its military power in global capitalism and look into a relative independency of state activity.

The relative independency is defined by the strategy and policies of the state. Fundamentally, characteristics of the economic base or structure of the country play a key role. However, sometimes a state 
counteractively provides huge effects on its economic activities altering the economic and social structure. In addition, the state or government can carry out independent performance relatively. Its independency is one of the important principles related to state activity in politics. Karl Marx formulated both the determination of economic foundation and relative independency of super-structure, for example, state and forms of ideology, etc. in his book Preface of Criticism of Political Economy in the middle of 19th century.

Japanese super-power nationalism is the major driving force, and the main promoter of great military power, with the purpose of achieving militaristic and diplomatic hegemony in East Asia and the west of the Pacific Ocean, and in the whole Asia, Pacific and Indian Oceans in the near future. Super-power nationalists whose major leader is Prime Minister Shinzoh Abe, one-time Prime Minister J. Koizumi, etc. have taken the reins of the government since the latter half of 1980s (except several years when the non-LDP party was in charge; for example, at the time of Democrat administration), and have come to maintain the hegemony in East Asia and the Western Pacific ocean by strengthening military force in this region.

The United States has held its military supremacy in this region in the era of post-Cold War, too. As the position of the US goes down while Japan increases its position, the co-hegemony of the US and Japan has been formed in the first decade of 21st century in this region, though Japan is militarily and diplomatically submissive to the US. Nowadays, co-hegemony of the US and Japan has come into collision with China, because China has become powerful militarily more and more, aiming to attain the hegemony in the same region.

We are severely critical of attaining military power and hegemonism, because we think that we should aim to ensure peace, i.e., political and social stability in this region by non-military means. A nationalist government does not drum up support from the majority of Japanese people for strengthening military power, hegemonism, and super-power nationalism, though we can partly observe the movement of nationalists, e.g., the group of Japanese Congress (Nihon-Kaigi). But in the case that the middle class who fear being affected may support a nationalist government, it may lead to the movement of super-power nationalists to support hegemonism in Japan.

However, there is a possibility that an alternative strategy of pacifism to aim international political and social stability by non-military means, rather than attaining military power, will be formed in Japan. And the author expects this movement will drum up support from the majority of people based on the same logic of relative independency. Pacifists would take the reins of the government, even though they are now in the minority.

\section{Conclusion}

Japan has been making policies to establish military power for more than 30 years, since the latter half of 1980s, along with the $1^{\text {st }}-7$ th government Mid-term Defense Plans. Consequently, Japan became a great military power in around 2015. The most important justification for this statement is that its Navy deployed four helicopter carriers, with a fleet each, that can independently perform military operations all the time in the wide area of the world. The existence of military power cannot be explained from the requirements of global capitals which have decreased the relationship with its nation state in global capitalism. Rather, it is explained by Japanese super-power nationalism and hegemonism, in other words, by the logic of relatively independent activity of state. 


\section{References}

Iida, K. (2011). A study of global capitalism (in Japanese). Tokyo: Nihon-keizai-Hyoronsya Publishing Company.

International Institute for Strategic Studies (IISS). (2017). Military balance. Retrieved from https://www.iiss.org/publications/the-military-balance/the-military-balance-2017

Japanese Defense Ministry. (1986-2018). Annual defense white paper. Retrieved from https://www.mod.go.jp/

Kayahara, I. (2018). The study of Chinese military force (in Japanese). Tokyo: The Institute of PHP.

Kayano, T. (2005). About the essence of state (in Japanese). Tokyo: Ibunsya Publishing Company.

Nakamura, H. (2017). The analysis of Japanese military force (in Japanese). Tokyo: KK Bestsellers.

Nakano, K. (2015). The analysis of the postwar politics in Japan (in Japanese). Tokyo: Iwanami Publishing Company.

Roseburg, J. (1994). The empire of civil society. London and New York, Verso.

SGCIME. (Ed.). (2016). The analysis of global capitalism and the theory of development stages (in Japanese). Tokyo: Ochanomizu-Shobo Publishing Company.

Smith, S. A. (1999). The evolution of military cooperation in the US-Japan alliance. In P. M. Cronin and M. J. Green (Eds.), The US-Japan alliance: Past, present, and future. New York: Council of Foreign Relations Press.

Teschke, B. (2003). The myth of 1648: Class, Geopolitics, and the Making of Modern International Relations. London and New York: Verso.

Todd, E. (2018). Japan should arm itself with nuclear weapons (translated into Japanese). The Journal of Bugei-Syunjyu, 96 (7), 94-103.

Uchiyama, A. (2013). The defense spending and ODA in Japan (in Japanese). In A. Uchiyama (Ed.), Textbook of public finance (Chapter 12). Tokyo: Zeimu-Keiri Publishing Company.

Uchiyama, A. (2018). Analysis of the military force and defense spending in the last 30 years (in Japanese). The Journal of Osaka University of Economics, 69(2).

Uchiyama. A. (2017). Global capitalism and new role of nation state (in Japanese). Ritsumeikan Journal of Economics, 65(6). 